\title{
Wands and other medical devices
}

Published at www.cmaj.ca on Feb. 24

A uthor Joseph Heller may have said it best in his novel Catch 22: "In confusion there is profit."

And confusion often finds the most fertile of breeding grounds as consumers attempt to weigh the advice coming at them before, during or after events like the pandemic (H1N1) 2009 influenza outbreak.

Bruce Cran, president of the Consumers' Association of Canada, warns that "often, a great range of remedies and cures seem to come on the market, some of which ... haven't been tested."

Even as the World Health Organization and Canada's chief medical officer of health urged Canadians to get vaccinated, frequently wash their hands and use alcohol-based hand sanitizers, novel treatments and products began surfacing on the market.

Those included such devices as the H1N1 Destroying UV (ultraviolet) Wand, which manufacturers said "eliminates the $\mathrm{H} 1 \mathrm{~N} 1$ virus from surfaces using safe UV-C light." Users were directed to hold the wand 1.9 centimetres above a contaminated surface for five seconds.

"UV light has some utility," notes Eleanor Fish, a microbiologist and senior research scientist at the Toronto General Research Institute in Ontario. But "the reality is that with something like a UV wand, it's the distance, it's the intensity of the light, it's the surface that you're waving this wand over. Is it marble? Is it glass? Is it wood? ... And how often is it tested to make sure it's working?"

An advertisement for the wand says it uses "the same technology trusted to sanitize hospital surfaces." The Ontario Hospital Association doesn't track this kind of information and therefore, is not sure $100 \%$ sure if any of its members hospitals use ultraviolet light to sterilize surfaces or not. But a spokeswoman for the University Health Network in

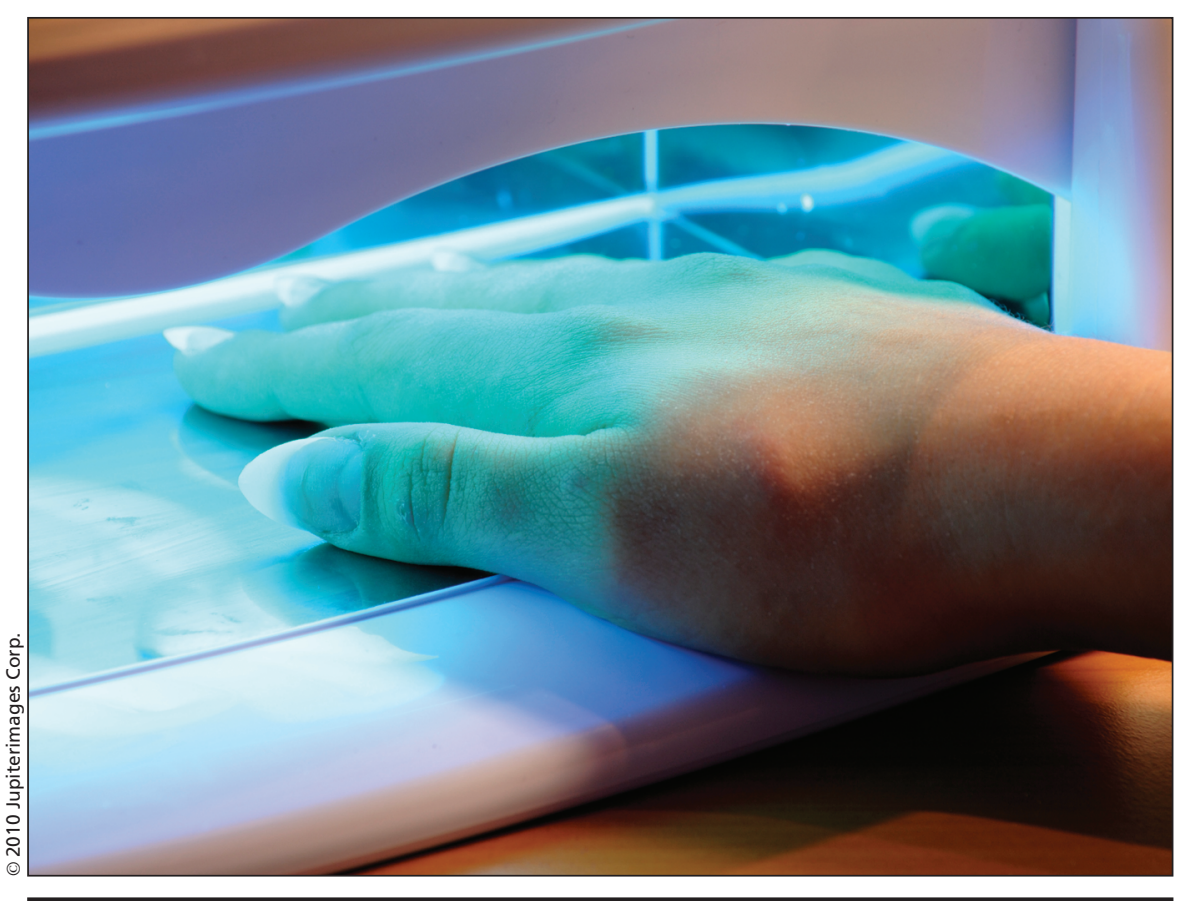

Ultraviolet light could have utility in dealing with flu viruses but there are serious limitations on potential value, says microbiologist Eleanor Fish.

Toronto, Ontario, says none of the network's facilities (Toronto General, Toronto Western and Princess Margaret) nor the Toronto Medical Laboratories, use UV light to sterilize surfaces.

The wand manufacturer also claims that "tests performed by an independent antimicrobial testing laboratory showed the wand destroyed $99.98 \%$ of the H1N1 virus," following the prescribed five-second exposure. The wand is also touted as being capable of killing "MRSA [methicillin-resistant Staphylococcus aureus], mold and dust mites," while penetrating "viral and bacterial membranes and destroys their DNA, rendering the microorganisms incapable of reproduction and survival."

Fish says she would not use it in her home. "Better off to get some sort of a strong detergent that might have bleach in it or a high level of alcohol and wipe down surfaces. But again, it depends what you're wiping them down with. If you're using a sponge that you've used a million times, it's going to be useless.
People have to put a little bit of thought behind what they are doing. Hand sanitizers are also useful, no question they've had an impact but they're not foolproof. Just sanitizing your hands doesn't mean you're going to be protected from the pandemic or from any virus."

There are several other devices on the market, such as the $\$ 239.95$ Mold and Germ Destroying Air Purifier, which claims to use air heated to $200^{\circ} \mathrm{C}$ "to destroy airborne mold, bacteria, viruses, dust mites, and pollens."

That "would buy a heck of a lot of soap," says Cran. "That was the main thing that governments throughout the world and the World Health Organization were recommending and still do for H1N1: Procedures for washing your hands and Purell, which is an alcoholbased decontaminent."

Another popular device in the postH1N1 era is something called "The Million Germ Eliminating Travel Toothbrush Sanitizer." 
According to one ad, "This compact device from VIOlight uses proven germicidal UV technology (the same kind trusted to sanitize hospital instruments) to eliminate up to $99 \%$ of the millions of germs that can accumulate on your toothbrush, including streptococcus and listeria."

"What's it protecting you from?" Fish queries. "The environment or what you've got in your mouth? ... They're not Health Canada-approved medical devices. People will tend to be reliant on them and I am just concerned that the public puts their confidence in these kinds of claims. That confidence has to be very carefully thought through."

Such products are not licensed by Health Canada, spokesman David Thomas wrote in an email. "The products listed would be either Class I (UV Wand and Mold and germ destroying air purifier) or Class II (Million-germ-killing toothbrush) devices. Health Canada does not license Class I devices and so does not do scientific reviews of the data supporting claims. For Class II devices, which are licensed by Health Canada, the manufacturer would have to have data to support the health claims, but the Department does not typically review the data unless there are safety concerns."

Yet, distributors don't appear to comprehend that distinction. When contacted, an employee taking telephone orders from the Hammacher Schlemmer catalogue, asserted that the devices are approved for sale in Canada.

Health Canada spokesman Gary Scott Holub clarifies that "Class I medical devices (UV Wand and Mold and Germ Destroying Air Purifier) do not require premarket approval. For a company to state that a class I device has been approved for sale in Canada by
Health Canada would not be accurate."

Also noticing a "spike" in the number of new medical devices appearing on the market in the aftermath of the pandemic is Competition Bureau Canada, an independent law enforcement agency that oversees false advertising.

Consumers need to "ask questions, be skeptical and speak to a health care professional who knows your medical history," before buying a medical device, says Tagreed Boules, senior competition law officer. "Some of these products may have side effects, or may interact with the person's medical history."

It's hard for consumers to verify online claims "because they don't have anyone to talk to," she adds. "The first alarm that should go off, is if it sounds too good to be true, it probably is." Becky Rynor, Ottawa, Ont.

DOI:10.1503/cmaj.109-3194 